\title{
The Analysis of Children's Development Associate Degree Program Students' Attitudes towards Inclusion in Preschool Period in Terms of Different Variables
}

\author{
Belgin Parlakyildiz \\ Cyprus International University, Lefkosa, Turkish Republic of Northern Cyprus \\ E-mail: bparlakyildiz@ciu.edu.tr \\ Semih Ucar \\ Mus Alparslan University, Mus, Turkey \\ E-mail: s.ucar@alparslan.edu.tr
}

\begin{abstract}
Preschool Education can be defined as an education that contributes to the development of the individual in every aspect and prepares the individual for his/her later stages. One of the main goals of preschool education is to create a common training environment for students from different backgrounds and families. In addition, pre-school education takes place based on some principles. One of the most important of these principles is the creation of educational environments that comply with individual differences and democratic educational philosophy. Students with special needs, just like children with a normal development, can benefit from this education with their peers in the best way possible only with a healthy inclusive education. The realization of a healthy inclusive education can be ensured by the sufficient involvement of all stakeholders who can take part in the inclusive education. This research was carried out to examine the attitudes of pre-school students towards inclusion in terms of different variables. The sample of the study consists of $\mathrm{N}=60$ students who are studying at Muş Alparslan University Malazgirt Vocational School in the spring term of 2018-2019 academic year. In the study, the "Attitude Scale Against Integration in Preschool Education" developed by Özbaba (2000) and "General Information Form" prepared by the researchers were used to determine the opinions of Child Development Associate Degree Program students about inclusion. Descriptive analysis was preferred in this study and quantitative research design was used. In the research, t-test and one-way anova were used to analyze and analyze the data. As a result of the research; it was concluded that there was no significant relationship between attitudes towards inclusion and gender, age, grade level, whether an individual requiring special education has been observed or not, and whether having received and integrated education or not.
\end{abstract}

Keywords: Preschool Education, Child Development, Inclusion, Attitude, Individual Requiring Special Education.

\section{Special Issue of Educational Sciences}

DOI: $10.7176 / J S T R / 6-06-08$

\section{Çocuk Gelişimi Ön Lisans Programında Öğrenim Gören Öğrencilerin Okul Öncesi Döneminde Kaynaştırmaya Yönelik Tutumlarının Farklı Değişkenler Açısından İncelenmesi}

\begin{abstract}
Özet
Okul Öncesi Eğitim, bireyin her yönü ile gelişimine katkı sağlayan ve bireyi yaşamını ileriki aşamalarına hazırlayan bir eğitim olarak tanımlanabilir. Okul öncesi eğitimin ana amaçlarından bir de farklı çevrelerden ve ailelerden gelen öğrenciler için ortak yetiştirme ortamı oluşturmaktır. Ayrıca okul öncesi eğitim bazı ilkelere dayanarak gerçekleşmektedir. Bu ilkelerin önemli olanlarından biri de bireysel farklılıklara ve demokratik eğitim felsefesine uyan eğitim ortamlarının oluşturulmasıdır. Normal gelişim gösteren çocuklar
\end{abstract}

$\mathbf{1 0 4} \mid \mathrm{P}$ a g e

www.iiste.org 
gibi özel gereksinimli öğrencilerin de akranları ile birlikte bu eğitimden en iyi şekilde yararlanmaları ancak sağlıklı bir kaynaştırma eğitimi ile mümkündür. Sağlıklı bir kaynaştırma eğitiminin gerçekleşebilmesi ise kaynaştırma eğitiminde yer alabilecek bütün paydaşların bu işe yeteri kadar dâhil edilmesi ile sağlanabilmektedir. $\mathrm{Bu}$ araştırma, çocuk gelişimi ön lisans öğrencilerinin okul öncesi dönemde kaynaştırmaya yönelik tutumlarının farklı değişkenler açısından incelemek amacıyla yapılmıştır. Çalışmanın örneklemini 2018-2019 eğitim öğretim yılı bahar döneminde Muş Alparslan Üniversitesi Malazgirt Meslek Yüksekokulu'nda öğrenim görmekte olan Çocuk Gelişimi Ön lisans birinci sınıf ve ikinci sınıf öğrencilerinden $\mathrm{N}=60$ öğrenci oluşturmaktadır. Çalışmada çocuk gelişimi ön lisans öğrencilerinin kaynaştırma hakkındaki görüşlerini belirlemek için Özbaba (2000)' tarafindan geliştirilen “Okul Öncesi Eğitimde Kaynaştırmaya Karşı Tutum Ölçeği’ ve öğrencileri tanımak için araştırmacıların hazırladığ "Genel Bilgi Formu" kullanılmıştır. Bu çalışmada betimsel analiz tercih edilmiş ve nicel araştırma deseni kullanılmıştır. Araştırmada verilerin analizi ve çözümlenmesi için t-testi ve tek yönlü anova kullanılmıştır. Araştırmada sonuç olarak; cevap aranan cinsiyet, yaş, sınıf düzeyi, daha önce özel eğitim gerektiren bir bireyi gözlemleyip gözlemlememe ve kaynaştırma eğitimi almış olma ve almamış olma değişkenleri ile kaynaştırmaya yönelik tutumlar arasında anlamlı bir ilişki olmadığı sonucuna ulaşılmıştır.

Anahtar Kelimeler: Okul Öncesi Eğitim, Çocuk Gelişimi, Kaynaştırma, Tutum, Özel Eğitim Gerektiren Birey.

\section{Giriş}

İnsanların yaşadıkları çevreye uyum sağlama ve kendi yeteneklerini keşfetme sürecinde oldukça önemli bir yeri olan eğitim, insan yaşamında sistemli bir şekilde ve yaşamının erken döneminde yer almalıdır. Bu önemli süreç içerisinde normal gelişim gösteren bireyler yer alırken aynı zamanda özel eğitim gerektiren bireyler de yer almaktadır. Eğitim bireylerin toplum içerisinde sosyalleşmesine, kültür aktarımına aracı olurken sadece normal gelişim gösteren bireyler için değil aynı zamanda normalden farklı, özel gereksinimi olan bireylerinde toplumla bütünleşmesine sistemli ve erkenden olanak sunmalıdır.

Özellikle çocukların yaşamlarının temelini oluşturan ve birçok beceriyi kazandıkları okul öncesi eğitim döneminde eğitim ortamlarının özel gereksinimli çocuklara göre düzenlenerek, kendi yaşıtlarıyla aynı ortamda eğitim almalarını sağlamak hem o süreçlerini hem de ileriki yıllarda yer alacakları sosyal ortamlarda önemli kazanımlar sağlayacaktır. Bu durum ise özel gereksinimli bireylerin normal olarak gelişim gösteren yaşıtları ile kaynaştırıldıkları eğitim ortamlarında sağlanabilir. Okul öncesi dönemde oluşturulan kaynaştırma eğitimi ortamı özel gereksinimi olan çocukların hem bireysel hem de toplumsal gelişimlerini olumlu yönde etkileyecektir (Metin, 2013). Erken yaşlarda verilmeye başlanan eğitim sadece normal olarak gelişim gösteren bireylerin ihtiyacı değil, aynı zamanda farklı nedenlerden dolayı normal gelişim gösteremeyen bireylerin de ihtiyacıdır (Odluyurt, 2012). Okul öncesi dönemde kaynaştırma erken çocukluk dönemindeki müdahalelerin en etkili yollarından biridir (Guralnick, 2016). Kaynaştırma Kırcalı (1992)'e göre, özel gereksinimli öğrencilere ve öğretmenlerine çeşitli destek hizmetlerin sağlanması amacıyla, özel gereksinimli bireylerin tam ya da yarı zamanlı olarak yaşıtlarıyla bir arada genel eğitim ortamlarında eğitim alması şeklinde tanımlanmaktadır.

Kaynaştırma programlarının öncelikli amacı, özel eğitime ihtiyacı olan öğrencilerin gelişimlerini hızlandırarak, içinde bulundukları topluluklara adaptasyon sağlamalarını kolaylaştırmak ve bunun yanında normal gelişim gösteren öğrencilerinde toplum içerisinde kendilerinden farklı özelliklere sahip olan öğrencileri kabul ederek uyum içerisinde yaşam becerileri kazanmalarını sağlamaktır. Sınıflarda yapılan kaynaştırma uygulamaları sadece engelli çocukların gelişimine fayda sağlıyor gibi görünse de, bununla beraber aynı ortamda bulunan tüm bireylere faydası olmaktadır (Metin, 2018).

Ülkemizde 2000 yılında çıkarılan 573 sayılı Kanun Hükmünde Kararname’de, özel eğitim hizmetlerinin eksikliklerinden etkilenen özel gereksinimli bireyleri çevreleriyle mümkün olduğu kadar bütünleştirerek planlama yapılması ve yaşam boyu öğrenme süreçlerini kapsayan tüm değişkenlerin (amaç, içerik $v b$.) düzenlenerek yetersizlikten etkilenen bireylerin normal gelişim gösteren yaşıtlarıyla bir arada kaynaştırılmalarına olanak sağlanmalıdır. Kararnamede okul öncesi eğitimim özel eğitim gerektiren bireyler için zorunlu olduğu ve bu eğitimin okul öncesi eğitim kurumları ve özel eğitim kurumları tarafindan verileceği de yer almaktadır (MEB, 1997).

Literatür incelendiğinde öğretmen adaylarının kaynaştırma eğitimine ilişkin görüş ve tutumlarının incelendiği (Okyay, Mutluer ve Peker, 2016; Öztürk, Ballığlu ve Şen, 2014; Aydın, Bozkurt ve Göçmen, 2017) araştırmalar bulunmaktadır. Ancak okul öncesi eğitimde çalışma potansiyeli yüksek olan çocuk gelişimi ön lisans öğrencilerinin kaynaştırma eğitimi ile ilgili tutumlarının araştırıldığı bir çalışmaya rastlanmamıştır. Hizmet öncesi dönemde hem çocuk gelişimi alanında çalışacak olan eğitimcilerin hem de

$\mathbf{1 0 5} \mid \mathrm{P}$ a g e

www.iiste.org 
okul öncesi eğitimci adaylarının, kaynaştırma eğitimi hakkında doğru bir şekilde bilgilendirilmeleri onların kaynaştırmaya yönelik tutumlarını olumlu bir şekilde etkileyecektir. $\mathrm{Bu}$ nedenle bu alanda çalışacak eğitimcilerin hizmete başlamadan önce aldıkları eğitim kaynaştırmaya ile ilgili tutumları ve buna bağlı olan diğer faktörleri belirlemek önem arz etmektedir.

Yapılan bu çalışma, Çocuk gelişimi ön lisans programında öğrenim gören öğrencilerin kaynaştırma eğitimine yönelik tutumlarını farklı değişkenler açısından incelemeyi amaçlamaktadır. Bu amaca yönelik aşağıdaki sorulara yanıt aranacaktır:

Çocuk Gelişimi ön lisans programındaki öğrencilerin,

a. Yaş değişkeni ile kaynaştırmaya yönelik tutumları arasında anlamlı bir farklılık var mıdır?

b. Cinsiyet değişkeni ile kaynaştırmaya yönelik tutumları arasında anlamlı bir farklılık var mıdır?

c. Öğrenim gördükleri sınıf düzeyi değişkeni ile kaynaştırmaya yönelik tutumları arasında anlamlı bir farklılık var midır?

d. Kaynaştırmaya yönelik eğitim alma durumu değişkeni ile kaynaştırmaya yönelik tutumları arasında anlamlı bir farklılık var midır?

e. Daha önce özel eğitim gerektiren bir bireyi gözlemleme durumu değişkeni ile kaynaştırmaya yönelik tutumları arasında anlamlı bir farklılık var midır?

\section{YÖNTEM}

\subsection{Araştırma Modeli}

Araştırmada, nicel araştırma yöntemleri arasında yer alan betimsel araştırma modellerinden tarama (survey) modeli kullanılmıştır. Bu model, belirli bir konu ve/veya olay ile ilgili katılımcıların görüşlerini, ilgilerini, becerilerini, yetenek ve/veya tutumlarını ortaya koyarak betimlemeye yardımc1 olan bir modeldir. Bu model kullanılarak çok geniş katılımcı kitlelerine ulaşılarak onların konu veya olaylar ile ilgili genel eğilimleri ortaya konulabilir. Tarama modeli ile gerçekleştirilen çalışmaların genel amacı çalışma konusuna yönelik var olan durumu betimleme yapmaktır (Büyüköztürk, 2007).

\section{2.Örneklem Grubu}

Bu çalışmanın örneklemini 2018-2019 eğitim öğretim yılı bahar döneminde Muş Alparslan Üniversitesi Malazgirt Meslek Yüksekokulunda öğrenim görmekte olan Çocuk Gelişimi Ön lisans birinci ve ikinci sınıf öğrencileri oluşturmaktadır. Çalışma için ikinci sınıflardan 30, birinci sınıflardan da 30 katılımcı genel bilgi formunu ve kaynaştırmaya yönelik tutum ölçeğini doldurmuşlardır. İkinci sınıf öğrencilerinin sayısı 30 olduğu için birinci sınıf öğrencilerinden de 30 katılımeı seçilmiş ki daha sağlıklı sonuçlara ulaşılsın. Belirlenenlerden toplam 60 kişi çalışmaya katılmayı kabul etmiş ve veri toplama araçlarını doldurmuşlardır.

\subsection{Veri Toplama Araçları}

\subsubsection{Genel Bilgi Formu}

Araştırmacı tarafından oluşturulan bu araç, katılımcıların kişisel bilgilerini ortaya koymak üzere kullanılmıştır. Toplam 5 sorudan oluşan bu bilgi formu;

a. Yaş,

b. Cinsiyet,

c. Öğrenim gördükleri sınıf düzeyi

d. Kaynaştırmaya yönelik eğitim alma durumu,

e. Daha önce özel eğitim gerektiren bir bireyi gözlemleme durumlarını öğrenmeyi amaçlamaktadır.

\subsubsection{Okul Öncesi Eğitimde Kaynaştırmaya Karşı Tutum Ölçeği}

$\mathbf{1 0 6} \mid \mathrm{P}$ a g e

www.iiste.org 
Araştırmada kaynaştırmaya yönelik tutumları ölçmek için Özbaba (2000) tarafından geliştirilen "Okul Öncesi Eğitimde Kaynaştırmaya Karşı Tutum Ölçeği’, kullanılmıştır. Ölçekte toplam 5'li Likert yapıda (tamamen katılıyorum, çok katılıyorum, katılıyorum, az katılıyorum ve hiç katılmıyorum) bulunan toplam 30 madde yer almaktadır. Ölçekten alınacak en yüksek puan 150, en düşük puan ise 30'dur. Ölçekten alınan puanın fazla olması kaynaştırmaya yönelik tutumun olumlu olduğunu, alınan puanın düşük çıkması durumunda kaynaştırmaya yönelik tutumun olumsuz olduğu anlamına gelmektedir.

\subsection{Veri Toplama Süreci}

Veriler, 2018-2019 eğitim öğretim yılının bahar döneminde Muş Alparslan Üniversitesi Malazgirt Meslek Yüksekokulunda öğrenim görmekte olan Çocuk Gelişimi Ön lisans birinci ve ikinci sınıf öğrencilerden gönüllü olarak katılan katılımcılardan toplanmıştır. Ölçeğin uygulanması için gereken müsaadeler alındıktan sonra ölçek uygulanarak veriler elde edilmiştir.

\subsection{Veri Analizi}

Verilerin analizinde SPSS 21 Paket Programı kullanılmıştır. Analiz iki aşamada gerçekleştirilmiştir. İlk aşamada, toplanan veriler tek tek spss programına işlenmiş ve betimsel analiz yardımıyla uç nokta, normal dağılım gösterme ve kayıp veri açısından analiz edilerek temizlenmiş ve yordamsal analizler için veri seti hazır hale getirilmiştir. İkici aşamada, temizlenen veri seti yordamsal analiz yardımıyla analiz edilmiştir. Parametrik testlerden bağımsız gruplar t-test analizi ve diğerleri için ANOVA Testi kullanılmıştır. Yordamsal analizler 0.05 anlamlılık düzeyinde gerçekleştirilmiştir.

\section{BULGULAR}

$\mathrm{Bu}$ bölümde çalışma sonucunda elde edilen verilerin SPSS programına işlenip düzenlendikten sonra, yapılan analizler sonucunda ulaşılan bulgular paylaşılmıştır. Tablo 3.1.'de araştırma verilerine ait normallik testi sonuçları verilmiştir.

Tablo 3.1.Ortalama verilerine ait Normallik testi

\begin{tabular}{lcccc}
\hline \multicolumn{5}{c}{ Kolmogorov-Smirnov } \\
\hline Grup & İstatistik & $\boldsymbol{f}$ & Sig. \\
\hline Ortalama & .101 & 60 & .200 \\
\hline
\end{tabular}

Tablo 3.1.'de yer alan veriler incelendiğinde çalışmaya katılan katılımcıların ölçek maddelerine verdiği cevapların normal bir dağılım gösterdiği görülmektedir. Ölçek maddelerine verilen cevaplara ait histogram grafiği Şekil 3.1.'de verilmiştir. Ölçek maddelerine verilen cevaplara ait nokta grafiği Şekil 3.2.' de verilmiştir.

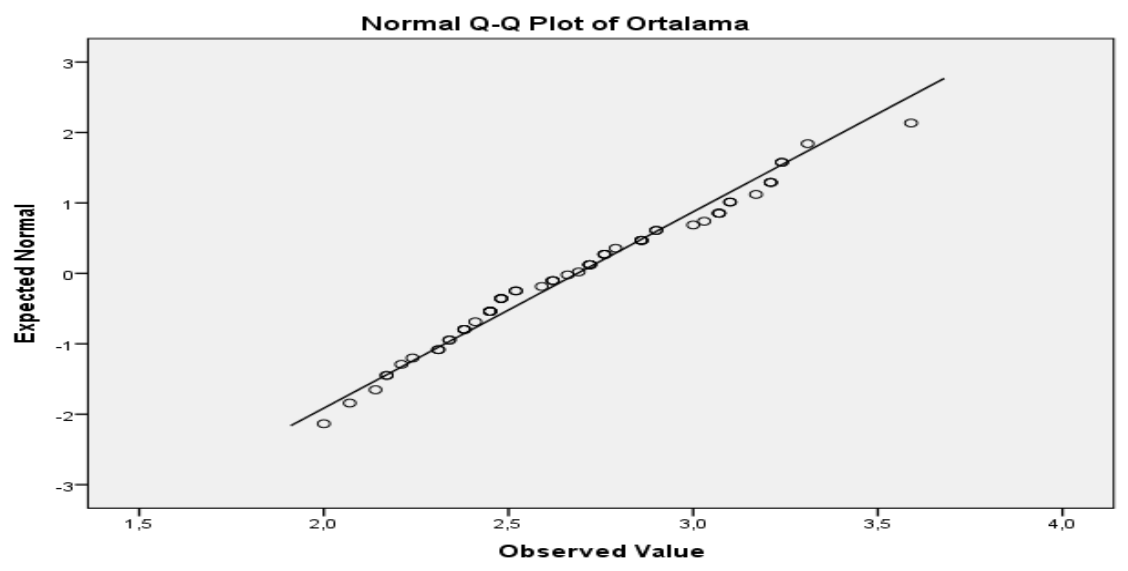

Şekil 3.1. Ölçek Maddelerine Verilen Cevaplara Ait Nokta Grafiği

$\mathbf{1 0 7} \mid \mathrm{P}$ a g e

www.iiste.org 
Şekil3.1.'deki veriler incelendiğinde çalışmaya katılan katılımcıların ölçek maddelerine vermiş oldukları cevaplara ilişkin normallik dağılımına ait nokta grfiğinde, verilen cevapların normal dağılım gösterdiği görülmektedir. Şekil 3.1.'deki grafik incelendiğinde ölçek maddelerine verilen cevaplarda normale yakın bir dağılım olduğu gözlenmektedir. Katılımcıların cinsiyet özelliklerine ait veriler Tablo 3.2.'de verilmiştir.

Tablo 3.2. Cinsiyetle ilgili frekans analizleri

\begin{tabular}{cccc}
\hline & f & \% & Toplam \% \\
\hline Kadın & 51 & 85 & 85 \\
Erkek & 9 & 15 & 100 \\
Toplam & 60 & 100 & \\
\hline
\end{tabular}

Tablo 3.2.'de yer alan veriler incelendiğinde çalışmaya katılan katılımcıların \% 85 (51) kadın ve \% 15 (9)'i ise erkek olduğu görülmektedir. Tabloda yer alan verilere dayanılarak katılımcıların büyük çoğunluğunun kadınlardan oluştuğu görülmektedir. Katılımcıların yaş özelliklerine ait veriler Tablo 3.3.'te verilmiştir.

Tablo 3.3. Yaşla ilgili frekans analizleri

\begin{tabular}{cccc}
\hline & f & \% & Toplam \% \\
\hline $\mathbf{1 8 - 2 5}$ & 58 & 96.7 & 96.7 \\
$\mathbf{2 6 - 3 3}$ & 1 & 1.7 & 98.3 \\
$\mathbf{3 4 - 4 1}$ & 1 & 1.7 & 100 \\
Toplam & 60 & 100 & \\
\hline
\end{tabular}

Yaşla ilgili frekans analizleri incelendiğinde Tablo 3.3.'te katılımcıların \% 96.7' si yani 58 kişi 18-25 yaş aralığında olduğu görülmektedir. Geriye kalan \% 2'lik kısım 26-33 ve 34-41 yaș aralığında olan birer kişi oluşturmaktadır. Yaş ile ilgili veriler incelendiğinde çalışmaya katılan katılımcıların büyük çoğunluğunun 18-25 aralığında olduğu görülmektedir. Katılımcıların sınıf düzeyi özelliklerine ait veriler Tablo 3.4.'te verilmiştir.

Tablo 3.4 . Sınıf düzeyi ile ilgili frekans analizleri.

\begin{tabular}{lccc}
\hline & f & $\%$ & Toplam \% \\
\hline 1.Sinıf & 30 & 50 & 50 \\
2.Sinıf & 30 & 50 & 100 \\
Toplam & 60 & 100 & \\
\hline
\end{tabular}

Sınıf düzeyi ile ilgili frekans analizleri incelendiğinde Tablo 3.4.’teki veriler incelendiğinde çalışmaya dahil edilen katılımcıların \% 50'si ( 30) birinci sınıf ve diğer \% 50'lik (30 ) kısmı ise ikinci sınıftan öğrencilerin olduğu görülmektedir. Katılımcıların daha önce özel eğitim gerektiren bir bireyi gözlemleme durumu özelliklerine ait veriler Tablo 3.5.’te verilmiştir. 
International Journal of Scientific and Technological Research

ISSN 2422-8702 (Online), DOI: 10.7176/JSTR/6-06-08

Special Issue of Educational Sciences, Vol.6, No.6, 2020

Tablo 3.5. Daha önce özel eğitim gerektiren bir bireyi gözlemleme durumu ile ilgili frekans analizleri.

f $\%$ Toplam \%

$\begin{array}{cccc}\text { Evet } & 49 & 81.7 & 81.7 \\ \text { Hayır } & 11 & 18.3 & 100 \\ \text { Toplam } & 60 & 100 & \end{array}$

Tablo 3.5.' te daha önce özel eğitim gerektiren bir bireyi gözlemleme durumu ile ilgili frekans analizleri incelendiğinde katılımcıların 49'unun (\% 81.7) daha önce özel eğitim gerektiren bir bireyi gözlemledikleri görülmektedir. Çalışmaya katılan katılımcıların 11'inin (\%18.3) ise daha önce özel eğitim gerektiren bir bireyi gözlemlemedikleri görülmektedir. Katılımcıların kaynaştırma ile ilgili eğitim alıp almama durumu özelliklerine ait veriler Tablo 3.6.'da verilmiştir.

Tablo3. 6. Kaynaştırma ile ilgili eğitim alıp almama durumu ile ilgili frekans analizleri.

\begin{tabular}{cccc}
\hline & f & $\%$ & Toplam \% \\
\hline Evet & 40 & 66.7 & 66.7 \\
Hayır & 20 & 33.3 & 100 \\
Toplam & 60 & 100 & \\
\hline
\end{tabular}

Tablo 3.6.'daki kaynaştırma ile ilgili eğitim alıp almama durumu ile ilgili frekans analizleri incelendiğinde katılımcıların \% 66.7'si (40) kaynaştırmayla ilgili eğitim aldıklarını belirtmişlerdir. Katılımcıların \% 33.3’ü (20) ise kaynaştırmayla ilgili eğitim almadıklarını belirtmişlerdir. Katılımcıların cinsiyet değişkeni ile kaynaştırma tutum puan ortalamaları bağımsız örneklem t-testi analiz sonuçlarına ait veriler Tablo 3.7.'de verilmiştir.

Tablo 3.7. Cinsiyet değişkeni ile kaynaştırma tutum puan ortalaması bağımsız örneklem T-Testi analiz

\begin{tabular}{ccccccc}
\hline Grup & N & Ort. & S.s & t & df & Sig(p) \\
\hline Kadın & 51 & 2.65 & .34 & & & \\
Erkek & 9 & 2.87 & .43 & -1.69 & & .096 \\
\hline
\end{tabular}

Tablo 3.7.'de verilen cinsiyet ve kaynaştırma tutum puan ortalaması bağımsız örneklem T-Testi analiz sonuçları incelendiğinde cinsiyet değişkeni ile kaynaştırmaya yönelik tutum arasında p(.096)> .05 değerine göre anlamlı bir farklılık bulunmamıştır. Katılımcıların sınıf düzeyi değişkeni ile kaynaştırma tutum puan ortalamaları bağımsız örneklem t-testi analiz sonuçlarına ait veriler Tablo 3.8.'de verilmiştir.

Tablo 3.8. Sınıf düzeyi değişkeni ile kaynaştırma tutum puan ortalaması bağımsız örneklem T-Testi analiz sonuçları.

\begin{tabular}{ccccccc}
\hline Grup & N & Ort. & s.s & t & df & Sig(p) \\
\hline 1.Sınıf & 30 & 2.73 & .38 & & 58 & .320 \\
2.Sınıf & 30 & 2.64 & .34 & 1.00 & & \\
\hline
\end{tabular}

$\mathbf{1 0 9} \mid \mathrm{P}$ a g e

www.iiste.org 
Sınıf düzeyi değişkeni ile kaynaştırma tutum puan ortalaması bağımsız örneklem T-Testi analiz sonuçları incelendiğinde sınıf düzeyi ile kaynaştırmaya yönelik tutumlar arasında $p(.320)>.05$ değerine göre anlamlı bir farklılık bulunmamıştır. Katılımcıların daha önce özel eğitim gerektiren bir bireyi gözlemleme durumu değişkeni ile kaynaştırma tutum puan ortalamaları bağımsız örneklem t-testi analiz sonuçlarına ait veriler Tablo 3.9.'da verilmiştir.

Tablo 3. 9. Daha önce özel eğitim gerektiren bir bireyi gözlemleme durumu değişkeni ile kaynaştırma tutum puan ortalaması bağımsız örneklem T-Testi analiz sonuçları.

\begin{tabular}{ccccccc}
\hline Grup & $\mathbf{N}$ & Ort. & s.s & t & df & Sig(p) \\
\hline Evet & 49 & 2.68 & .35 & & & \\
Hayır & 11 & 2.73 & .40 & -.470 & & .640 \\
\hline
\end{tabular}

Daha önce özel eğitim gerektiren bir bireyi gözlemleme durumu değişkeni ile kaynaştırma tutum puan ortalaması bağımsız örneklem T-Testi analiz sonuçları incelendiğinde, özel eğitim gerektiren bireyi gözlemlememe durumu ile kaynaştırmaya yönelik tutumlar arasında $\mathrm{p}(.640)>.05$ değerine göre anlamlı bir farklılık bulunmamıştır. Katılımcıların kaynaştırma ile ilgili eğitim alma durumu değişkeni ile kaynaştırma tutum puan ortalamaları bağımsız örneklem t-testi analiz sonuçlarına ait veriler Tablo 3.10.'da verilmiştir.

Tablo 3.10. Kaynaştırma eğitimi alma durumu değişkeni ile kaynaştırma tutum puan ortalaması bağımsız örneklem T-Testi analiz sonuçları.

\begin{tabular}{ccccccc}
\hline Grup & $\mathbf{N}$ & Ort. & S.s & t & df & Sig(p) \\
\hline Evet & 40 & 2.66 & .35 & & & \\
Hayır & 20 & 2.73 & .40 & -.669 & & .506 \\
\hline
\end{tabular}

Kaynaştırma ile ilgili eğitim alma durumu değişkeni ile kaynaştırma tutum puan ortalaması bağımsız örneklem T-Testi analiz sonuçları incelendiğinde kaynaştırma eğitimi almış olma veya olama durumu değişkeni ile kaynaştırmaya yönelik tutum arasında $p(.506)$ >.05 değerine göre anlamlı bir fark bulunmamıştır. Katılımcıların yaş değişkeni ile kaynaştırma tutum puan ortalamaları ANOVA testi analiz sonuçlarına ait veriler ve çalışmaya katılan öğrenci sayıları $(\mathrm{N})$, puanlarının ortalaması $(\overline{\mathbf{X}})$, standart sapma değerleri (ss); gruplar arası ve gruplar içi kareler toplamı, serbestlik dereceleri (df), ortalamalarının kareleri, Levene F değeri ve Sig. (p) değerleri Tablo 3.11.'de verilmiştir.

Tablo 3. 11. Yaş değişkeni ile kaynaştırma tutum puan ortalaması ANOVA Testi analiz sonuçları

\begin{tabular}{|c|c|c|c|c|c|c|c|c|c|}
\hline \multicolumn{4}{|c|}{$f, \overline{\mathbf{x}}$ ve $s s$ Değerleri } & \multicolumn{6}{|c|}{ ANOVA Sonuçları } \\
\hline Grup & $\mathbf{N}$ & $\overline{\mathbf{x}}$ & Ss & & $\begin{array}{l}\text { Kareler } \\
\text { toplamı }\end{array}$ & df & $\begin{array}{c}\text { Ort. } \\
\text { karesi }\end{array}$ & $\mathbf{F}$ & Sig. \\
\hline $18-25$ & $\begin{array}{l}5 \\
8\end{array}$ & 2.69 & .36 & G. aras1 & .35 & 2 & .18 & & \\
\hline $26-33$ & 1 & 2.14 & . & G. içi & 7.24 & 57 & .13 & 1.381 & .260 \\
\hline $34-41$ & 1 & 2.48 & . & Toplam & 7.59 & 59 & & & \\
\hline Toplam & $\begin{array}{l}6 \\
0\end{array}$ & 2.68 & .36 & & & & & & \\
\hline
\end{tabular}

$\mathbf{1 1 0} \mid \mathrm{P}$ a g e

www.iiste.org 
Tablo 3.11.'deki veriler incelendiğinde, katılımcıların 18-25 yaş aralığındaki 58 kişinin kaynaştırma tutumları puan ortalaması 2.69 olduğu görülmektedir. Yaş aralığ1 26-33 olan bir kişilik katılımcının kaynaştırma tutumları puan ortalaması 2.14 tür. Geriye kalan bir kişinin ise 34-41 yaş aralığında olduğu ve kaynaştırma tutumları puan ortalamasının ise 2.48 olduğu görülmektedir. Toplamda incelediğimizde katılımcıların puan ortalamaları 2.68 olduğu ve standart sapmalarının toplamının ise .36 olduğu görülmektedir. Çalışmaya katılan katılımcıların yaş değişkenleri ile kaynaştırmaya yönelik tutumları arasında $\mathrm{p}(.260)>.05$ değerine göre anlamlı bir ilişki bulunamamıştır. Ayrıca anova testi için yapılan homojenlik testinde dağılımın homojenlik göstermediği sonucuna ulaşılmıştır.

\section{Sonuç ve Tartışma}

Araştırma elde edilen sonuçlara göre, çalışmaya katılan katılımcıların ölçek maddelerine verdiği cevapların normal bir dağılım gösterdiği görülmüştür. Çalışmaya katılan katılımcıların büyük çoğunluğunun kadın katılımcılar olduğu ve katılımcıların büyük çoğunluğunun 18-25 yaş aralığında olduğu görülmüştür. Bu sonuca göre çocuk gelişiminde okuyan öğrencilerin kadın ağırlıklı ve genç yaşta bireyler olduğu söylenebilir. Çalışmaya katılan katılımcıların \% 81.7'si daha önce özel eğitim gerektiren bir bireyi gözlemlediklerini belirtmişlerdir. Buna göre katılımcıların büyük çoğunluğunun daha önce özel eğitim gerektiren bir bireyi gözlemledikleri söylenebilir. Çalışmaya katılan katılımcıların \% 66.7'si (40) kaynaştırmayla ilgili eğitim aldıkları, katılımcıların \% 33.3’ü (20) ise kaynaştırma ile ilgili alakalı eğitim almadıkları görülmüştür. Bu durumun öğrencilerin bazılarının lisede ve ikinci sınıf öğrencilerinin müfredatında yer alan kaynaştırma eğitimi dersi ile ilgili olduğu söylenebilir.

Kaynaştırmaya yönelik tutumlar ve değişkenler arasındaki anlamlılığın incelendiği analiz sonuçlarına göre: cinsiyete ile kaynaştırmaya yönelik tutum arasında $\mathrm{p}(.096)>.05$ değerine göre anlamlı bir farklılık saptanmamıştır. Göçmen, Bozkurt ve Aydın (2017), okul öncesinde kaynaştırma konulu anne eğitim programının çıktılarının anne ve öğretmen görüşlerine göre değerlendirilmesine öğretmen adaylarının kaynaştırmaya yönelik tutumlarını inceledikleri çalışmalarında cinsiyet ile kaynaştırmaya yönelik tutumlar arasında anlamlı ilişki bulmamışlardır. Bek, Gülveren ve Başer (2009) sınıf öğretmeni adaylarının kaynaştırma eğitimine yönelik tutumlarını inceledikleri çalışmalarında cinsiyet ile kaynaştırmaya yönelik tutumlar arasında anlamlı ilişki bulmamışlardır. Ekşi (2010) sınıf öğretmenleri ve özel eğitim öğretmenlerinin kaynaştırma eğitimi ile ilgili tutumlarının karşılaştırılması adlı çalışmasında; Güleryüz ve Özdemir (2015) sınıf öğretmeni adaylarının kaynaştırmaya ilişkin tutumlarını inceledikleri çalışmalarında cinsiyet değişkeni ile kaynaştırmaya yönelik tutumlar arasında anlamlı bir farklılık olmadığını bulmuşlardır. Bu çalışmalardan elde edilen sonuçlar ile yaptığımız çalışmanın sonuçları paralellik göstermektedir.

Sınıf düzeyi değişkeni ile kaynaştırmaya yönelik tutum arasında $p(.320)>.05$ değerine göre anlamlı bir farklılık saptanmamıştır. Daha önce özel eğitim gerektiren bir bireyi gözlemleyip gözlemlememe durumu ile kaynaştırmaya yönelik tutumları arasında $\mathrm{p}(.640)>.05$ değerine göre anlamlı bir farklılık saptanmamıştır. Özdemir (2010) okul öncesi öğretmenlerinin kaynaştırmaya ilişkin görüşlerini incelediği çalışmasında, özel eğitim gerektiren bireyler ile çalışmayan öğretmenlerin kaynaştırma eğitimine yönelik tutumları ile çalışmayan öğretmenlerin tutumları arasında çalışmayanlar lehine anlamlı bir fark olduğu sonucuna ulaşmıştır. Bu çalışmanın sonuçları ile yaptığımız çalışmanın sonuçları farklılık göstermektedir. Değer (2018) ise yönetici ve öğretmenlerin kaynaştırmaya yönelik tutumlarını incelemek amacıyla yaptığ1 çalışmasında, kaynaştırmaya yönelik tutumlar ile daha önce özel eğitim gerektiren bir birey ile çalışma değişkeni arasında anlamlı bir fark olmadığı sonucuna ulaşmıştır. Bu çalışmadan elde edilen sonuçlar ile yaptığımız çalışmanın sonuçları paralellik göstermektedir.

Kaynaştırma ile ilgili eğitimi almış olma veya olama durumu değişkeni ile kaynaştırmaya yönelik tutum arasında $p(.506)>.05$ değerine göre anlamlı bir fark saptanmamıştır. Değer (2018) ve Ekşi (2010) yapmış oldukları çalışmalarda kaynaştırma ile ilgili eğitim alma durumu arasında anlamlı bir farklılık olmadığ sonucuna ulaşmışlardır. Bu çalışmaların sonuçları yapılan bu çalışma ile paralellik göstermektedir. Özdemir (2010) ve Avramidis, Bayliss ve Burden R (2000), gerçekleştirdikleri çalışmalarında kaynaştırma ile ilgili eğitim alan öğretmenlerin kaynaştırma ile ilgili eğitim almayan öğretmenlere göre kaynaştırma eğitimine yönelik daha olumlu tutumları olduğunu belirtmişlerdir. Bu sonuçlar ile bu çalışmamızın sonuçlarının birbirlerinden farklı olduğu görülmektedir.

Çalışmaya katılan katılımcıların yaş değişkenleri ile kaynaştırmaya yönelik tutumları arasında $\mathrm{p}(.260)>.05$ değerine göre anlamlı bir ilişki saptanmamıştır. Buna göre, Özdemir(2010), Cankaya (2010), Ekşi (2010) ve Değer (2018)'in yapmış oldukları çalışmalarının sonuçlarında yaş ile kaynaştırmaya yönelik tutumlar arsında anlamlı bir farklılık olmadığı görülmüştür. Bu çalışmalar, yaptığımız çalışmanın sonucunu destekler nitelikte sonuçlara ulaşılmış iken, Pamuk (2016) ve Ertunç (2008)'in yapmış oldukları

$\mathbf{1 1 1} \mid \mathrm{P}$ a g e

www.iiste.org 
çalışmalarında yaş ile kaynaştırmaya yönelik tutumlar arasında anlamlı bir farklılık olduğu ve yaşın kaynaştırmaya yönelik tutumları etkilediği sonucuna ulaşmışlardır. $\mathrm{Bu}$ iki çalışmanın sonucu ile çalışmamızda elde edilen sonuçlar arasında farklılık bulunmaktadır.

Sonuç olarak cevap aranan cinsiyet, yaş, sınıf düzeyi, özel eğitim gerektiren bireyi gözlemlememe ve kaynaştırma eğitimi almış olama veya olmama değişkenleri ile kaynaştırmaya ilişkin tutumlar arasında anlamlı bir ilişki olup olmadı̆̆ı sorularının hepsine de cevap olarak anlamlı bir ilişkinin bulunmadığı sonucuna ulaşılmıştır.

Kaynaştırma eğitiminin temel amacı, özel gereksinime ihtiyacı olan çocukların içinde yaşadıkları topluma uyum becerilerinin sağlanmasıdır. Bu uygulamaların toplumda farklılıklara duyarlı ve özel gereksinime ihtiyacı olan bireylerin kabulünde de artış göstereceği düşünülmektedir. Kaynaştırma programlarının amacına ulaşmasında en etkili kişi olan eğitimcilerin bu çocuklarla karşılaşmadan önce farkındalık sahibi olmaları bu eğitime ilişkin olumlu tutum geliştirmelerinde önem arz etmektedir.

Not: Bu çalışma, 23-25 Ağustos 2019 tarihinde Rize'de gerçekleştirilen Karadeniz Zirvesi 2.Uluslararası Sosyal Bilimler Kongresinde bildiri olarak sunulmuştur.

\section{Kaynakça}

Avramidis, E., Bayliss, P., Burden, R. (2000). A survey into mainstream teacher's attitudes towards the inclusion of children with special educational needs in the ordinary school in one local education authority. Educational Psychology, 20(2), 24-26.

Bek, H., Gülveren, H. ve Başer, A. (2009). Sınıf Öğretmen Adaylarının Kaynaştırma Eğitimine Yönelik Tutumlarının İncelenmesi. Uşak Üniversitesi Sosyal Bilimler Dergisi 2(2), 160-168.

Büyüköztürk, Ş. (2007). Sosyal Bilimler Iç̧in Veri Analizi El Kitabı. Ankara: Pegem Akademi Yayınları.

Cankaya, Ö. (2010). İlköğretim ı. kademede kaynaştırma ĕgitimi uygulamalarının sınıf öğretmenlerinin görüşlerine göre değerlendirilmesi. (Yüksek Lisans Tezi). Selçuk Üniversitesi Eğitim Bilimleri Enstitüsü, İlköğretim Ana Bilim Dalı Sınıf Öğretmenliği Bilim Dalı.

Çamlıbel, Ö., Çetin Eldeniz M. (2016). Okul Öncesi Öğretmenlerinin Kaynaştırmaya Yönelik Gereksinimlerinin Belirlenmesi, The Journal of Academic Social Science Studies, Number: 43 , p. 259-274

Değer, Ş. (2018). Yönetici ve öğretmen görüşlerine göre okul öncesi dönemde kaynaştırma eğitimi uygulamalarına yönelik tutumların incelenmesi. (Yüksek Lisan Tezi) Kırklareli Üniversitesi, Sağlık Bilimleri Enstitüsü, Kırklareli.

Ekşi, K. (2010). Sınıf öğretmenleri ile özel ĕgitim öğretmenlerinin kaynaştırma eğitimi ile ilgili tutumlarının karşılaştırılması. ( Yüksek Lisans Tezi). Marmara Üniversitesi, Eğitim Bilimleri Enstitüsü İlköğretim Ana Bilim Dalı. Sınıf Öğretmenliği Bilim Dalı, İstanbul.

Ertunç, N. (2008). Kaynaştırma ĕgitimi uygulanan ilköğretim ikinci kademede görev alan beden eğitimi ögretmenlerinin kaynaştırma eğitimi hakkındaki bilgi düzeylerinin ve sınıflarındaki engelli ögrencilere bakış açılarının değerlendirilmesi. ( Yüksek Lisans Tezi).Gazi Üniversitesi Eğitim Bilimleri Fakültesi Beden Eğitimi ve Spor Öğretmenliği Ana Bilim Dalı, Ankara.

Göçmen Mutlu, N., Bozkurt, M., \& Aydın, Ç. (2017). Sınıf öğretmeni adayları ile özel eğitim öğretmen adaylarının kaynaştırma eğitimine yönelik tutumlarının karşılaştırılması. Kafkas Ĕ̆itim Araştırmaları Dergisi, 4(1), 26-33.

Güleryüz, B. ve Özdemir, M. (2015). Sınıf Öğretmenlerinin ve Sınıf Öğretmeni Adaylarının Kaynaştırma Eğitimine İlişkin Tutumlarının İncelenmesi. Uşak Üniversitesi Sosyal Bilimler Dergisi. 8 (3). 53-64.

$\mathbf{1 1 2} \mid \mathrm{P}$ a g e

Www.iiste.org 
International Journal of Scientific and Technological Research

ISSN 2422-8702 (Online), DOI: 10.7176/JSTR/6-06-08

Special Issue of Educational Sciences, Vol.6, No.6, 2020

Guralnick, M. (2016). Early interventin for children with intellectual disabilities. An update, Journal of Applied Research in intellectual Disabilities, 1-19.

Kırcaali İftar, G. (1992). Özel eğitimde kaynaştırma. Eğitim ve Bilim Dergisi, 16, 45-50.

Metin, N. (2018). Okul öncesi kaynaştırma sınıfında öğretmen. Erken Çocukluk Çalışmaları Dergisi 5.Uluslararası Okul Öncesi Eğitim Kongresi Özel Sayısı, 2(2), 428-439.

Metin, Ş. (2013). Türkiye'de okul öncesi kaynaştırmaya ilişkin yapılan çalışmaların incelenmesi. Bayburt Üniversitesi, Eğitim Fakültesi Dergisi, 4(1), 159- 185.

MEB. (1997). Özel Eğitim Hakkında Kanun Hükmünde Kararname ve Özel Eğitim Hizmetleri Yönetmeliği, Özel Eğitim Rehberlik ve Danışma Hizmetleri Genel Müdürlüğ̈̈,Ankara.http://orgm.meb.gov.tr/meb_iys_dosyalar/2012_10/10111011_ozel_egitim_ka nun_hukmunda_kararname.pdf(Erişim: 13.03.2019).

Okyay, Ö., Mutluer, C., Peker, G. (2016). Okul öncesi öğretmen adaylarının kaynaştırma eğitimine yönelik tutumlarının incelenmesi. Milli Ĕ̈itim Dergisi, 212, 27-44.

Odluyurt, S. (2012). Okul Öncesi Kaynaştırma. İçinde S. Batu, A. Çolak ve S. Odluyurt. Özel Gereksinimli Çocukların Kaynaştırılması (s.139-171).Ankara: Vize Yayıncılık.

Öztürk, H., Ballığlu, G., Şen, G. (2014). Öğretmen adaylarının özel eğitimde kaynaştırma uygulamalarına yönelik tutumlarının incelenmesi. Muğla Ĕgitim Fakültesi Dergisi, Cilt 1, Sayı 1, Mayıs 2014.

Özdemir, H. (2010). Okul öncesi öğretmenlerinin kaynaştırma uygulamasına ilişkin görüşlerinin incelenmesi. (Yüksek lisans Tezi). Trakya Üniversitesi, Sosyal Bilimler Enstitüsü, Edirne.

Özbaba, N. (2000). Okul öncesi eğitimcilerinin ve ailelerin özel eğitime muhtaç çocuklar ile normal çocukların entegrasyonuna (kaynaştırılmasına) karşı tutumları. ( Yüksek Lisans Tezi). Marmara Üniversitesi, Eğitim Bilimleri Enstitüsü, İstanbul.

Pamuk, Y. (2016). Sını öğretmenlerini kaynaştırmaya ilişkin görüşlerinin incelenmesi. (Yüksek lisans Tezi). Dokuz Eylül Üniversitesi, Eğitim Bilimleri Enstitüsü, İlköğretim Anabilim Dalı Sınıf Öğretmenliği Programı, İzmir. 